\title{
MHRD'S INITIATIVE IIC CONTRIBUTION TOWARDS INNOVATION IN HIGHER EDUCATIONAL INSTITUTIONS DURING COVID 19
}

\author{
Dr. Esha Jain \\ The NorthCap University, Gurugram, Haryana, India \\ Jonika Lamba \\ The NorthCap University, Gurugram, Haryana, India
}

\begin{abstract}
Innovation is the word which means new idea, creative thought, and practical implementation of invention. The MHRD initiative IIC is helpful for the students to learn entrepreneurship skills in their initial years of graduation and nurture them till completion of their qualification. The innovation cell of higher educational institutions will enhance the skills, aptitude of the students and prepare them for future endeavors. The main motive of MIC Innovation Cell is to inspire, persuade and cherish young and talented students to work with innovative thoughts and convert their ideas into prototypes and cherish their work. The e-sessions by the IIC-Institutes will overcome the need for physical innovation cell activities which is impossible in current situation due to COVID-19 pandemic. The quarter 3 and 4 have been merged into one period because of ongoing pandemic i.e., one complete semester and all IIC institutes have to report accordingly for the scores and star ratings. The e-sessions by IIC institutes have been successful and gathered appreciation from students and faculty members. There is a growing awareness that entrepreneurial outlook, which combines inventiveness, a sense of initiative, predicament solving, vagueness tolerance and financial and technological knowledge in formal education for benefit of individuals and society. The MHRD initiative of IIC will enable the foundation of robust modernization and Start up ecosystem across all HEIs.
\end{abstract}

Key words: Innovation, IIC, Entrepreneurship, HEI, MIC, HEInnovate, COVID 19

\section{INTRODUCTION}

The prolonged lockdown in the country due to Covid-19 pandemic have led to many changes in the country. Education industry is not an exception to this situation and has undergone several changes in past few months. The continuous efforts of Ministry of Human Resource Department (MHRD) in the field of higher education are remarkable and they are taking steps so that pace of learning is uninterrupted. Institutions Innovation Council (IIC), initiative of HRD Ministry have designed 17 electronic sessions in the field of Innovation, Intellectual Property Rights (IPRs), Startups/Entrepreneurship as digital activities for all IIC institutes in the IIC networks. The basic idea behind the program is that students should be abreast of latest innovations in the country and their skills can be capitalized in the startup initiative activities. These digital activities are the substitute of the physical activities to be undertaken by IIC-institutes as part of IIC calendar activities which are hard to organize now due to medical emergency in the nation. There has been active participation in e-sessions by the students as well as by the faculty members. With the help of these sessions' students got the opportunity to enhance their present skills and learn new ways of doing things. The budding entrepreneurs got the much-needed platform to showcase their business plan and seek finance from angel investors. These digital sessions have motivated students to broaden their thinking and find new ways of doing things. Change is the only thing, which is constant today, so innovation is the need of successful entrepreneurs. The rating and scores of higher educational institutions depends on the activities undertaken by respective institutions in the field of innovation, entrepreneurship, startups and Intellectual Property Rights (IPRs). The activities in prescribed domain by IIC-institutions will have bearing on their star rating. These activities counted towards annual score and star calculations upon submission of annual report at IIC 


\section{Yinternational Research Journa!}

p-ISSN 2202-2821 e-ISSN 1839-6518 (Australian ISSN Agency)

portal. For this, Q3 and Q4 have been now merged to one period i.e., semester to provide cushion to many higher educational institutions to take active part and submit their reports on time.

\section{Review of Literature}

Garavan, T. N., \& Barra, O. (1994) highlighted the troubles and shortcomings faced by students in the entrepreneurship learning and training programs. It was found that major problem was the imbalance between knowledge and proficiency of the students, too much focus on transferring education techniques instead of educating by making petite groups as development teams, individual psychotherapy, and workshops. No such apparatus for assessment of such training sessions. It was also found that there is lack of proportional research to recognize commonalities and differences in terms of designs and structure.

Kirby, D. A. (2004) examined the personality and function of the entrepreneur and the challenges for B-Schools posed by the need to develop more enterprising individuals. The successful entrepreneurs were created with the help of proper training programs and on the job preparation in entrepreneurship training sessions. The traditional education system was just rendering the theoretical knowledge about entrepreneurship education which failed to develop requisite skills and attributes in the prospective entrepreneurs. The process of learning needs to be altered so that students could have practical exposure of entrepreneurs and startup culture. It suggested that emphasis should be given from "about" entrepreneurship to educating "for" it. Focus should be on imagination and change. The present training structure should be modified to make it more robust and enhance the skill set and analytical skills of prospective entrepreneurs.

Mok, K. H. (2005) studied what kind of policy, University in Hong Kong adopted to persuade entrepreneurship fortitude and practices by cheering academic personnel to venture in industrialized, business, and marketable fields. The study examined how universities in Hong Kong reform their core curriculum to make students more ingenious and innovative. It reflected the role of Hong Kong Special Administrative Region (HKSAR) in promoting innovation, entrepreneurship with significant orientation to communications between government, the tertiary education sector and private segment in promoting a vivacious and active economy.
Vol. 11 No. 012021

82801101202110

Rasmussen, E. A., \& Sørheim, R. (2006) presented several action-based activities to promote innovation and startup actions at five Swedish universities. This study focused on learning by doing and motivated graduates to transform their ideas into reality. The paper showed that teaching in classroom setting is less effective and learning by doing in network and group setting is more beneficial for the students. Various initiatives have been taken with multiple objectives such as focusing university research on innovation cell, promoting budding entrepreneurs, building new business, etc. Implications for setting up an action-oriented entrepreneurship education programs were also discussed in the paper. Innovation could help to be competitive at firm level as well as national front.

Solomon, G., \& Matlay, H. (2008) explored the impact of entrepreneurship education on outcomes in the arena of invention and private enterprise education. The study investigated the apparent impact that many private enterprise curriculums have had on a group of sixty-four graduate businesspersons from eight higher educational institutions in the United Kingdom. The data was collected for 10-year cycle starting from 1997 to 2006 to record, assess and evaluate respondent's development from graduation day to successful entrepreneurs.

Oosterbeek et al. (2010) analyzed the influence of a foremost entrepreneurship training curriculum on university student's entrepreneurship competences and inspiration applying influential variables methodology in a difference-indifferences framework. The study exploited that the curriculum was suggested to the learners at one spot of a university and not at another spot of same university. The result showed that the curriculum did not have the predicted outcome and impacts on student's self-assessment entrepreneurship competences were inconsequential and the effect on goal to become successful entrepreneurs was even negative.

Surie, G. (2014) emphasized that a country requires a robust higher education system and public laboratories to accumulate scientific, hi-tech and novelty capabilities. Universities should produce trained and capable personnel to promote innovation and entrepreneurship in the country. The study addresses answers to question based on role of university in the advancement of science, technology, and innovation

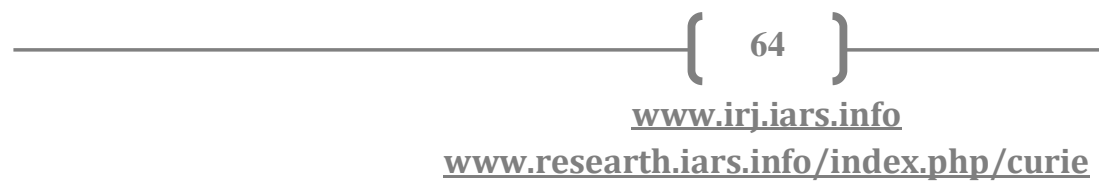




\section{Yinternational Research Journa}

p-ISSN 2202-2821 e-ISSN 1839-6518 (Australian ISSN Agency)

capabilities in India and how university and engineering conglomerate put into social development in India.

Hofer, A. R., \& Baur, P. (2018) studied the development of entrepreneurial capacity of citizens and organizations across Europe have been key objective for EU and its member states. There is a growing awareness that entrepreneurial outlook, which combines inventiveness, a sense of initiative, predicament solving, vagueness tolerance and financial and technological knowledge in formal education for benefit of individuals and society. There were heavy expectations from the policy makers to promote entrepreneurships and innovation at the higher education institutions. This study focused on start-up support in HEIs and framed the term HEInnovate.

Dhage, S. N., \& Ghadge, R. (2019) tried to through light on education sector before 2019. India had become second largest platform for digital learning after US. The paper studied various strategies, policies, recent trends which can help India in becoming No. 1 in e-learning platform. The study highlighted key initiatives of government of India in promoting higher education and strengthened key policies for promotion of apex education institutions and improves the quality of education as well. The government is promoting the education sector so that it can contribute more to increasing GDP of the nation.

\section{Objectives of the study}

The study has been conducted to achieve the following objectives:

1. To examine the contribution of IIC, initiative of Ministry of Human Resource Department towards innovation in the higher educational institutions during COVID19.

2. To study the e-sessions taken up by IIC institutes to strengthen the pace of learning in the field of innovation, startups, entrepreneurship, and intellectual property rights (IPRs).

\section{Methodology}

The information gathered in this study has been taken from secondary sources of data collection including authentic sources as well as past studies. The study is a descriptive analysis of the measures undertaken by Ministry of Human Resource Department towards innovation in the higher educational institutions in the period of global distress. The
Vol. 11 No. 012021

82801101202110

digital sessions by IIC institutes will enhance the skill set of budding entrepreneurs and motivate them for doing things in new manner. To remain competitive in the market innovation, smoothen the process of growth and acceptance in the stiff rivalry.

\section{A. Focus of Institution's Innovation Council (IIC)}

The focus of these activities is to create vibrant local innovation ecosystem and to support startups and budding entrepreneurs at the initial stage of idea generation. It will also prepare institutes for the Atal Ranking of Institution on innovation achievement framework. The MHRD IIC esessions will help in building cognitive ability and problemsolving attitude among the technology students.

\section{B. Functions of Institution's Innovation Council (IIC)}

- $\quad$ To carry out various innovation and entrepreneurship unified activities prescribed by MHRD IIC Innovation Cell.

- To recompense the best innovation projects and share success stories in public domain.

- Helps in creating network with peers and worldwide innovation cells and entrepreneurship development organization.

- To organize various seminars, workshops, business plan competitions, interactive sessions with professionals and venture capitalists as well as angel investors.

- To create innovation portal to highlight the achievement of students and faculty in the field of innovation and entrepreneurship.

C. Major program initiatives of MHRD Innovation Cell towards promoting Innovation, IPR and Startup ecosystem in HEIs

- Establishing Institution's Innovation Council (IIC) and actively organizing activities in campus.

- $\quad$ E-learning on innovation, IPR and Entrepreneurship using MOOC platform SWAYAM of MHRD.

- Adoption and implementation of National Innovation and Startup Policy (NISP) for students and faculties in HEIs. 


\section{Yinternational Research Journal}

p-ISSN 2202-2821 e-ISSN 1839-6518 (Australian ISSN Agency)

- Adoption of Induction and Internship Policy of AICTE and Orientation students on Innovation Entrepreneurship as Alternative Career Options

- Participation in Atal Ranking of institutions on Innovation Achievement (ARIIA) for HEIs.

- Regularly conducting Internal Hackathons and Participation of Students in Smart India Hackathon (SIH).

\section{V.Program Analytics}

Due to COVID 19 impact, the physical conduct of any programme was not possible. So, to follow the COVID 19 directions issued by Government of India, Ministry of Education conducted all the programmes and sessions online through various platforms. MIC (former MHRD's Innovation Cell, now Ministry of Education Innovation Cell) YouTube Channel received appreciation from the audience and the idea of premiering through YouTube was successful. To examine the understanding of the audience every session was followed by e-assignment for participants. There was total 17 online sessions on topics such as Role and importance of preincubators, Incubators, and accelerators in HEIs, National Innovation and startup policy for students and faculty 2019. A guiding framework for HEIs for implementation, Hangout with successful startup founder, Role of Network Enablers in driving in Innovation and Entrepreneurship in HEIs- A Case of TiE, India, Hangout with emerging Innovators \& Entrepreneurs Supported through MIC \& AICTE, Intellectual Property(IP) Management at Early Stage of Innovation and Start-ups and many more knowledge enhancing topics were taken up in the e-sessions by Central MIC innovation cell, There was phenomenal participation of students and faculties. MIC YouTube Channel has achieved the milestone of 1 million views in total since its inception. All the sessions were different and complementing each other. The eminent speakers of the e-sessions were expert in their respective fields and enlighten the latent entrepreneurial skills of the students. The duration of the e-sessions was compact and learning material was also provided post e-sessions. The Google forms were used to collect student's feedback at the end of each session. The students were made to analyze themselves in the field of entrepreneurship and develop analytical skills to channelize their ideas into successful business plans. The concepts related to entrepreneurship education were taken
Vol. 11 No. 012021

82801101202110

from the elementary education in the arena of innovation and startup world and later sessions on funding were taken up. All the sessions were organized in the systematic manner and students found sessions relevant and useful. The students were also made aware about the reasons behind such initiatives taken up by the MHRD Innovation Cell and how fruitful they will prove for the nation growth and development.

\section{Findings}

- As per the report of IIC $52.5 \%$ females and $47.4 \%$ males have attended the online sessions conducted by MIC.

- The significant portion of audience lays in the age group of 18-24 years i.e., $61.3 \%$ which shows sessions were catering to the needs of young audience.

- $99.5 \%$ of the audience was from India only.

- The online sessions were found useful and interesting to the students and faculty members.

- Session on Product Innovation Rubric (PIR) based on Innovation Risk Diagnostic was found very much interesting to the students.

- Students found the sessions inspiring youngsters and the budding engineers.

- Students and faculty members appreciated initiative of MIC to refresh the young minds of talented and enthusiastic college students.

- Faculties found the sessions very informative and acknowledge the efforts of government to set up startup ecosystem in higher educational institutions even during COVID times by providing online learning.

- Students and faculty members realized the need for practical training for implementing the business plans and need for transformation from traditional training sessions to more robust and innovative practical training sessions where students can exploit their skills and aptitude.

- Sessions on Innovating Self-Screen and Identify right opportunities help students to select right business avenue from different alternatives available. 
- $\quad$ Students get to know about the legal and ethical steps need to be complied with while starting new and innovative business.

- Institutes must cultivate and execute Innovation and Entrepreneurship scheme and strategy for the whole organization to incorporate the innovative endeavors beyond different regions, faculties, departments, inside the institutes.

- Sessions on Intellectual property management at early stage of Innovation and Start-ups helped students to understand IPRs and their implication on the new businesses.

- Technical sessions on entrepreneurship and innovation in the initial years of graduation to the students provide sufficient time to explore and cherish ample opportunities available before them to turn mere business idea into promising business ventures.

- $\quad$ Students found E-sessions by IIC practical based and knowledge enhancing.

- Experts from different sessions were able to resolve all the students' queries in the field of innovation and entrepreneurship.

\section{Conclusion}

The MHRD initiative of IIC was excellent step in the field of promoting innovation, startups, entrepreneurships, and Intellectual Property Rights (IPRs). Due Covid-19 the learning pace have been bit slowed down but the enthusiastic steps by the government in education domain and innovation activities helped to gain knowledge of transforming ideas into reality. The e-sessions by the IIC-institutions have received appreciation from students and faculty members. The sessions were based on challenging issues in the meadow of innovation and entrepreneurship. The talented and hardworking students can reap maximum benefits from such programs and turn their business ideas into reality. Students get to know about the legal and ethical steps need to be complied with while starting new and innovative business. Sessions on Innovating SelfScreen and Identify right opportunities help students to select right business avenue from different alternatives available. Institutes must cultivate and execute Innovation and Entrepreneurship scheme and strategy for the whole organization to incorporate the innovative endeavors beyond different regions, faculties, departments, inside the institutes. Sessions on Intellectual property management at early stage of Innovation and Start-ups helped students to understand IPRs and their implication on the new businesses. The interaction with venture capitalists and angel brokers provides students the requisite knowledge about fund raising activity and what factors need to be taken care of while approaching venture capitalists and angel brokers for injection of funds in new businesses. Technical sessions on entrepreneurship and innovation in the initial years of graduation to the students provide sufficient time to explore and cherish ample opportunities available before them to turn mere business idea into promising business ventures. Students and faculties found the sessions very informative and acknowledged the efforts of government to set up startup ecosystem in higher educational institutions. The process of learning needs to be altered so that students could have practical exposure of entrepreneurs and startup culture.

\section{REFERENCES}

[1]. Bantanur, S., Mukherjee, M., \& Shankar, R. (2009). Sustainability Practices and leadership in Higher Educational Campuses of India. Social Sciences, 8(2).

[2]. Dhage, S. N., \& Ghadge, R. (2019). A Research Article on the Study of Recent Trends, Strategies and Opportunities in Higher and Professional Education in India. Sumedha Journal of Management, 8(3), 292299.

[3]. Garavan, T. N., \& Barra, O. (1994). Entrepreneurship education and training programmes. Journal of European industrial training.

[4]. Hofer, A. R., \& Baur, P. (2018). 10 Graduate entrepreneurship support: what higher education institutions do, and how government can support them. Entrepreneurship and Local Economic Development: A Comparative Perspective on Entrepreneurs, Universities and Governments, 92.

[5]. Huggins, R., \& Johnston, A. (2009). The economic and innovation contribution of universities: a regional perspective. Environment and Planning C: Government and Policy, 27(6), 1088-1106.

[6]. Kaur, R., \& Singla, D. S. (2019). Performance Measurement of Higher Educational Institutions: An Empirical Study Using Student's Perception. Journal of Management, 6(2). 
[7]. Kirby, D. A. (2004). Entrepreneurship education: can business schools meet the challenge?. Education+ training.

[8]. Koneru, I. (2017, August). Administering MHRD guidelines-compliant eAssessments through Moodle. In 2017 5th National Conference on E-Learning \& ELearning Technologies (ELELTECH) (pp. 1-6). IEEE.

[9]. Krishna, V., \& Patra, S. (2015). Research and innovation in Universities in India. India higher education report.

[10]. Lamba, J., \& Jain, E. (2020). Covid-19 PandemicBountiful For MSMES and Indian Economy. Purakala, 31(33), 89-94.

[11]. Maithreyi, R., \& Prabha, K. (2019). The Vocationalisation of Secondary and Higher Secondary Education (VSHSE) program was introduced in 2013 by the Ministry of Human Resource and Development (MHRD) to offer optional vocational courses in schools, alongside academic subjects. A national vocational training program has been available in India since the $1950 \mathrm{~s}$, while a vocational education program was introduced in the 1980s with the aim of providing avenues. A Critical Sociological Analysis of the Skills Development Initiative of India, 6.

[12]. Mok, K. H. (2005). Fostering entrepreneurship: Changing role of government and higher education governance in Hong Kong. Research Policy, 34(4), 537-554.

[13]. Mukherjee, T. UGC MHRD ePG Pathshala.

[14]. Oosterbeek, H., Van Praag, M., \& Ijsselstein, A. (2010). The impact of entrepreneurship education on entrepreneurship skills and motivation. European economic review, 54(3), 442-454.

[15]. Panday, P. N. 10th National Research Conference of AIMA "Integrating Technology in Management Education" 28-29 March 2016, India International Centre (IIC), New Delhi.

[16]. Pandian, S. R. (2016). Affordable robotics for innovative education and outreach. CSI Communications, 40(4), 7-11.

[17]. Panigrahi, J. (2018). Innovative financing of higher education: Changing options and implications. Higher Education for the Future, 5(1), 61-74.

[18]. Piuri, V., Balas, V. E., Borah, S., \& Ahmad, S. S. S. (Eds.). (2019). Intelligent and Interactive Computing: Proceedings of IIC 2018 (Vol. 67). Springer.

[19]. Qamar, F. (2018). Measuring Performance of Higher Education Institutions (HEIs) and the National Institutional Ranking Framework (NIRF). India
Higher Education Report 2017: Teaching, Learning and Quality in Higher Education.

[20]. Rasmussen, E. A., \& Sørheim, R. (2006). Actionbased entrepreneurship education. Technovation, 26(2), 185-194.

[21]. Rohatgi, D. (2017). The contribution of various Government policies and schemes in facilitating and fostering an inclusive, innovative, technology enabled stable Industrial Growth with enhanced R\&D investments. Proceedings of the Indian National Science Academy, 83(1).

[22]. Shah, K. (2018). Online Media for Higher Education: Contributions of Consortium for Educational Communication in India. Global Media Journal: Indian Edition, 10(1).

[23]. Solomon, G., \& Matlay, H. (2008). The impact of entrepreneurship education on entrepreneurial outcomes. Journal of small business and enterprise development.

[24]. Surie, G. (2014). The University as a Catalyst of Innovation, Entrepreneurship, and New Markets in the Indian System of Innovation. Innovation in India: Combining Economic Growth with Inclusive Development, 39-77.

[25]. Walia, P., \& Manju, M. (2018). Reforms And Initiatives In Higher Education System. MIER Journal of Educational Studies, Trends and Practices, 8(1).

[26]. Yeravdekar, V., \& Tiwari, G. (2012). The higher education system in India and its impact on the economy. Available at SSRN 2139894. 


\section{Manuscript Processing Footprints}

\section{A. Journal Volume/Issue Details}

This manuscript it published in Vol. 11 No. 012021 issue of IARS' International Research Journal (I'IRJ).

This is a Peer Reviewed (Refereed) International Journal archived with National Library of Australia.

The mentioned Volume/Issue is a special issue of the journal dedicated to Covid19 Pandemic Conditions across globe.

\section{B. Citation}

Jain, Esha, Lamba, Jonkia (2021) "MHRD'S INITIATIVE IIC CONTRIBUTION TOWARDS INNOVATION IN HIGHER EDUCATIONAL INSTITUTIONS DURING COVID 19”, IARS' International Research Journal. Vic. Australia, 11(1). Available at: https://researth.iars.info/index.php/curie

\section{Author Declaration}

- The submission has not been previously published, nor is it before another journal for consideration (or an explanation has been provided in Comments to the Editor).

- The submission file is in OpenOffice, Microsoft Word, or RTF document file format.

- Where available, URLs for the references have been provided.

- The text is single-spaced; uses a 12-point font; employs italics, rather than underlining (except with URL addresses); and all illustrations, figures, and tables are placed within the text at the appropriate points, rather than at the end.

- The text adheres to the stylistic and bibliographic requirements outlined in the Author Guidelines.

- All Terms and Conditions about submission and publishing with IARS' International Research Journal on its official site and other sources have been gone through, understood, and accepted.

- With submission, this is declared that the submitter has all rights of the content, and to submit it. Also the submitter affirms that the rights of the submitted content are hereby transferred to IARS' international Research Journal and its parent company/publisher, without objections or conditions.

\section{Last Plagiarism Report}

Settings : similarity of 09 words in a row considered plagiarized.

\section{Originality Assessment}

\section{Overall Similarity: 70}

Date: Jan 12, 2021

Statistics: 244 words Plagiarized / 3668 Total words Remarks: Low similarity detected, check your supervisor if changes are required. Exemption / Relaxation by Editor: None

\section{E. Processing Track}

\begin{tabular}{|l|l|}
\hline Date of Submission: & 08 November 2020 \\
\hline Date of Referee/Review - 1: & 27 November 2020 \\
\hline Date of Referee/Review - 2: & 29 December 2020 \\
\hline Date of Additional Review: & NA \\
\hline Date of Acceptance: & 12 January 2021 \\
\hline Date of Publishing: & 08 February 2021 \\
\hline
\end{tabular}

